\title{
STUDI MODEL ESTIMATOR WAKTU KERJA PEMESINAN BUBUT PADA UJI KOMPETENSI PRAKTIK KEJURUAN BIDANG PEMESINAN
}

\author{
Ratna Wati ${ }^{1}$, Wardaya ${ }^{2}$, Purnawan ${ }^{3}$ \\ Universitas Pendidikan Indonesia \\ J1. Dr. Setiabudhi No.229 Bandung 40154 \\ ratna.wati@student.upi.edu
}

\begin{abstract}
ABSTRAK
Penelitian ini bertujuan untuk menghasilkan model estimator waktu kerja pemesinan, dan format penilaian waktu kerja pada uji kompetensi praktik kejuruan bidang pemesinan. Metode yang digunakan pada penelitian ini adalah deskriptif korelasional dengan subjek penelitian sebanyak 30 siswa. Data dikumpulkan melalui observasi langsung pada pelaksanaan uji kompetensi praktik kejuruan untuk pekerjaan membubut yang meliputi proses bubut rata muka, bubut rata, bubut ulir luar, bubut chamfer, bubut alur, dan bor center. Hasil penelitian menunjukkan bahwa model linear $\mathrm{T}_{\mathrm{m}}=15.021+4.250 \mathrm{~T}_{\mathrm{c}}$ dapat digunakan sebagai model estimator waktu kerja pemesinan pada uji kompetensi praktik kejuruan pemesinan bubut. Format penilaian waktu pemesinan yang dihasilkan dikelompokan ke dalam empat nilai yaitu waktu pemesinan selama < 171 menit; 171,5-187 menit; 187,5-203; dan > 203 menit berturut-turut dengan nilai A, B, C, dan E.
\end{abstract}

Kata kunci: model estimator, waktu kerja pemesinan, uji kompetensi

\section{PENDAHULUAN}

Pengukuran keterampilan praktik siswa SMK dalam satu bidang tertentu dilakukan dengan uji kompetensi. Kegiatan ini bertujuan untuk mengukur pencapaian kompetensi siswa pada level tertentu sesuai kompetensi keahlian yang ditempuh (Badan Standar Nasional Pendidikan, 2015). Penilaian uji kompetensi dilakukan oleh assesor atau penguji. Siswa yang dinyatakan kompeten akan lulus dan mendapatkan sertifikat pernyataan kompeten, sedangkan siswa yang belum kompeten harus mengulang hingga mendapat kategori kompeten. Assesor melakukan penilaian dengan mengisi lembar penilaian yang telah disediakan oleh Badan Standar Nasional Pendidikan (BSNP). Lembar penilaian tersebut memuat persiapan kerja, proses, hasil kerja, sikap kerja, dan waktu.

Lembar penilaian kriteria waktu penyelesaian Uji Praktik Kejuruan yang dikeluarkan oleh BSNP (2016) memuat waktu dan hasil kerja, padahal waktu dan hasil kerja adalah dua aspek yang berbeda. Waktu menunjukkan seberapa cepatnya siswa menyelesaikan produk kerja, sedangkan hasil kerja menunjukkan kualitas dari produk yang dihasilkan. Apabila diperhatikan, nilai yang diperoleh peserta Uji Praktik Kejuruan dalam aspek waktu belum dapat membedakan dengan jelas mana peserta Uji Praktik Kejuruan yang menyelesaikan pekerjaan dengan cepat dan mana yang termasuk dalam kategori sedang atau bahkan lambat.

\footnotetext{
${ }^{1}$ Mahasiswa Departemen Pendidikan Teknik Mesin FPTK UPI

2 Dosen Departemen Pendidikan Teknik Mesin FPTK UPI

${ }^{3}$ Dosen Departemen Pendidikan Teknik Mesin FPTK UPI
} 
Hal ini karena belum adanya standar waktu yang spesifik. Selain itu, siswa yang menyelesaikan pekerjaan tidak tepat waktu pun di beri nilai, padahal penyelesaian pekerjaan yang tidak tepat waktu adalah hal yang merugikan bagi perusahaan. Penyelesaian produk yang tidak tepat waktu menyebabkan biaya produksi bertambah, selain itu juga menyebabkan tidak tercapainya target produksi suatu perusahaan.

Aspek penilaian waktu penyelesaian uji kompotensi yang dikeluarkan oleh BSNP nyatanya masih terdapat beberapa hal yang perlu dikritisi, diantaranya penyatuan aspek waktu dan hasil kerja yang merupakan dua aspek berbeda. Tidak terdapat hubungan yang positif dan signifikan antara waktu kerja pemesinan terhadap hasil kerja pada pelaksanaan uji kompetensi praktik kejuruan bidang pemesinan (Adiranti, et. al2016). Aspek waktu dan hasil kerja pada instrumen penilaian waktu kerja pemesinan harus dipisah, untuk menilai kecepatan penyelesaian pekerjaan harus ditentukan terlebih dahulu lamanya waktu penyelesaian secara teoritis. Penyatuan aspek waktu dan hasil kerja pada instrumen penilaian waktu kerja pemesinan tidak tepat. Penilaian waktu kerja pemesinan harus sesuai dengan hasil perhitungan waktu setiap urutan proses pekerjaan secara teoritis. Fakta tersebut, menjelaskan bahwa penilaian aspek waktu yang dikeluarkan oleh BSNP masih perlu dilakukan pembaharuan agar mampu menggambarkan dengan jelas kompetensi pencapaian waktu peserta uji kompetensi.

Waktu pemesinan adalah salah satu aspek yang dinilai dalam uji kompetensi. Waktu pemesinan mencakup dua hal yaitu waktu produktif dan waktu non produktif. Waktu produktif adalah waktu yang digunakan untuk menyayat benda kerja atau dapat disebut dengan waktu pemotongan. Waktu non produktif adalah waktu yang digunakan di luar penyayatan benda kerja seperti pengaturan mesin, penyiapan mesin beserta perlengkapannya, dan sebagainya. Waktu pemotongan berhubungan dengan waktu pemesinan pada uji kompetensi praktik kejuruan bidang pemesinan bubut dengan tingkat hubungan kuat (Nugraha, et. al. 2015). Hasil penelitian tersebut menunjukkan bahwa terdapat hubungan yang sangat kuat antara waktu pemotongan dan waktu pemesinan pada pelaksanaan uji komptensi praktik kejuruan teknik pemesinan bubut (Ramadhan, et. al., 2015).

Adanya hubungan yang erat antara waktu pemotongan dan waktu pemesinan menjadikan kedua variabel. Penelitiann ini untuk menemukan model estimator waktu kerja pemesinan bubut pada uji kompetensi praktik kejuruan bidang pemesinan. Formula yang valid untuk menentukan waktu penyelesaian produk uji kompetensi keahlian teknik 
pemesinan sangat diperlukan, sehingga dapat memberikan estimasi berapa waktu ideal untuk menyelesaikan sebuah benda kerja pada mesin bubut.

Penggunaan model estimator waktu kerja pemesinan bubut dapat menghasilkan penilaian aspek waktu yang objektif (Karyadi, et. al. 2014). Rata-rata waktu pemesinan penyelesaian produk dalam proses pembubutan adalah 213 menit. Waktu pemesinan pada pekerjaan membubut masuk dalam empat kategori dengan pesentase 13\%, 27\%, 53\% dan 7\% masing -masing untuk kategori A, B, C dan D.

\section{METODE PENELITIAN}

Metode yang digunakan adalah deskriptif korelasional. Pengumpulan data dilakukan dengan menghitung waktu kerja pemesinan secara langsung pada pelaksanaan uji kompetensi pemesinan bubut menggunakan stopwatch. Waktu pemesinan dihitung ketika siswa mulai berdiri di depan mesin sampai dengan benda kerja selesai dan mesin kembali dirapihkan seperti keadaan semula.

Populasi penelitian merupakan siswa SMK kelas XII keahlian teknik pemesinan tahun ajaran 2016/2017 sebanyak 136 siswa. Pengambilan sampel dengan teknik random sampling yaitu teknik pengambilan sampel yang ditentukan secara acak. Teknik penambilan sampel ini dipilih karena syarat pengujian data salah satunya adalah pengambilan sampel secara acak. Jumlah sampel sebanyak 30 responden.

\section{HASIL PENELITIAN}

Hasil penelitian menunjukkan bahwa dalam menyelesaikan benda kerja, waktu pemesinan maksimum 325 menit, waktu pemesinan minimum 109 menit, waktu pemotongan maksimum 74.23 menit, waktu pemotongan minimum 25.76 menit, rata-rata waktu pemesinan 225.7667 menit, rata-rata waktu pemotongan 49.5897 menit, standar deviasi waktu pemesinan 58.24543 menit, dan standar deviasi waktu pemotongan 12.34249 menit.

Hasil pengujian normalitas dan korelasi data menunjukkan data berdistribusi normal dan kedua variabel memiliki hubungan yang signifikan dengan tingkat hubungan yang sangat kuat (koefisien kolerasi sebesar 0,91). Uji regresi dua variabel menggunakan curve estimation menghasilkan beberapa model estimator.

Estimasi dengan model linear menunjukkan nilai koefisien kolerasi sebesar 0,811. Uji kelinearan, nilai sig. Pengujian menunjukkan $(0,00)<(0,05)$ sehingga Ho ditolak. Jadi model linear signifikan. Uji konstanta dan koefisien, koefisien b memiliki nilai sig. $(0,00)<(0,05)$ 
sehingga Ho ditolak. Jadi baik konstanta maupun koefisien b signifikan. Hal ini menunjukkan bahwa model linear cocok digunakan sebagai model estimator waktu kerja pemesinan bubut. Persamaan linear yang terbentuk adalah $\mathrm{T}_{\mathrm{m}}=15.021+4.250 \mathrm{~T}_{\mathrm{c}}$.

Estimasi dengan model logaritma menunjukkan nilai koefisien kolerasi sebesar 0,77. Uji kelinearan, nilai sig. Pengujian menunjukkan $(0,00)<(0,05)$ sehingga Ho ditolak. Jadi model logaritma signifikan. Uji konstanta dan koefisien, koefisien b memiliki nilai sig. Pengujian menunjukkan $(0,00)<(0,05)$ sehingga Ho ditolak. Konstanta maupun koefisien $b$ signifikan. Hal ini menunjukkan bahwa model logaritma cocok digunakan sebagai model estimator waktu kerja pemesinan bubut. Persamaan logaritma yang terbentuk adalah $T_{m}=-$ $531.281+195.516 \ln \mathrm{T}_{\mathrm{c}}$.

Estimasi dengan model quadrat menunjukkan nilai koefisien kolerasi sebesar 0,812. Uji kelinearan, nilai sig. Pengujian menunjukkan $(0,00)<(0,05)$ sehingga Ho ditolak. Jadi model quadrat signifikan. Uji konstanta dan koefisien, koefisien b memiliki nilai sig. Pengujian menunjukkan $(0,00)<(0,05)$ sehingga Ho ditolak. Jadi baik konstanta maupun koefisien b signifikan. Hal ini menunjukkan bahwa model quadrat cocok digunakan sebagai model estimator waktu kerja pemesinan bubut. Persamaan quadrat yang terbentuk adalah $\mathrm{T}_{\mathrm{m}}$ $=42.837+3.080 \mathrm{~T}_{\mathrm{c}}+0.012 \mathrm{~T}_{\mathrm{c}}{ }^{2}$.

Estimasi dengan model exponensial menunjukkan nilai koefisien kolerasi sebesar 0.768. Uji kelinearan, nilai sig. Pengujian menunjukkan $(0,00)<(0,05)$ sehingga Ho ditolak. Jadi model exponensial signifikan. Uji konstanta dan koefisien, koefisien b memiliki nilai sig. Pengujian menunjukkan $(0,00)<(0,05)$ sehingga Ho ditolak. Konstanta maupun koefisien b signifikan. Hal ini menunjukkan bahwa model exponensial cocok digunakan sebagai model estimator waktu kerja pemesinan bubut. Persamaan exponensial yang terbentuk adalah $\mathrm{T}_{\mathrm{m}}=\ln 83.775+0.019 \mathrm{~T}_{\mathrm{c}}$.

\section{PEMBAHASAN}

Empat model berpotongan pada dua titik yang sama (Gambar 1). Hal ini menunjukkan bahwa keempat model memiliki karakteristik yang serupa, sehingga keempat model tersebut dapat digunakan sebagai model estimator waktu kerja pemesinan bubut. Namun, nilai koefisien kolerasi tertinggi dari keempat model tersebut adalah model quadrat $(0,82)$ dan linear $(0,81)$ sehingga kedua model inilah yang menjadi model terbaik untuk dipilih.

Dua titik pertemuan dari keempat kurva model estimator yaitu $(34,66$ dan 162,33$)$ dan (61,33 dan 275,67), sehingga keempat model ini mampu memprediksi waktu pemesinan dengan rentang waktu pemotongan antara 34,66 sampai 61,33 menit. Berdasarkan aturan 
pemilihan, model dengan nilai koefisien kolerasi tertinggi adalah model yang harus dipilih. Namun, perbedaan persamaan quadrat dan linear adalah 1,43\% di bawah taraf kesalahan 5\% sehingga dapat dikatakan perbedaan kedua model tidak signifikan.

\section{waktu pemesinan}

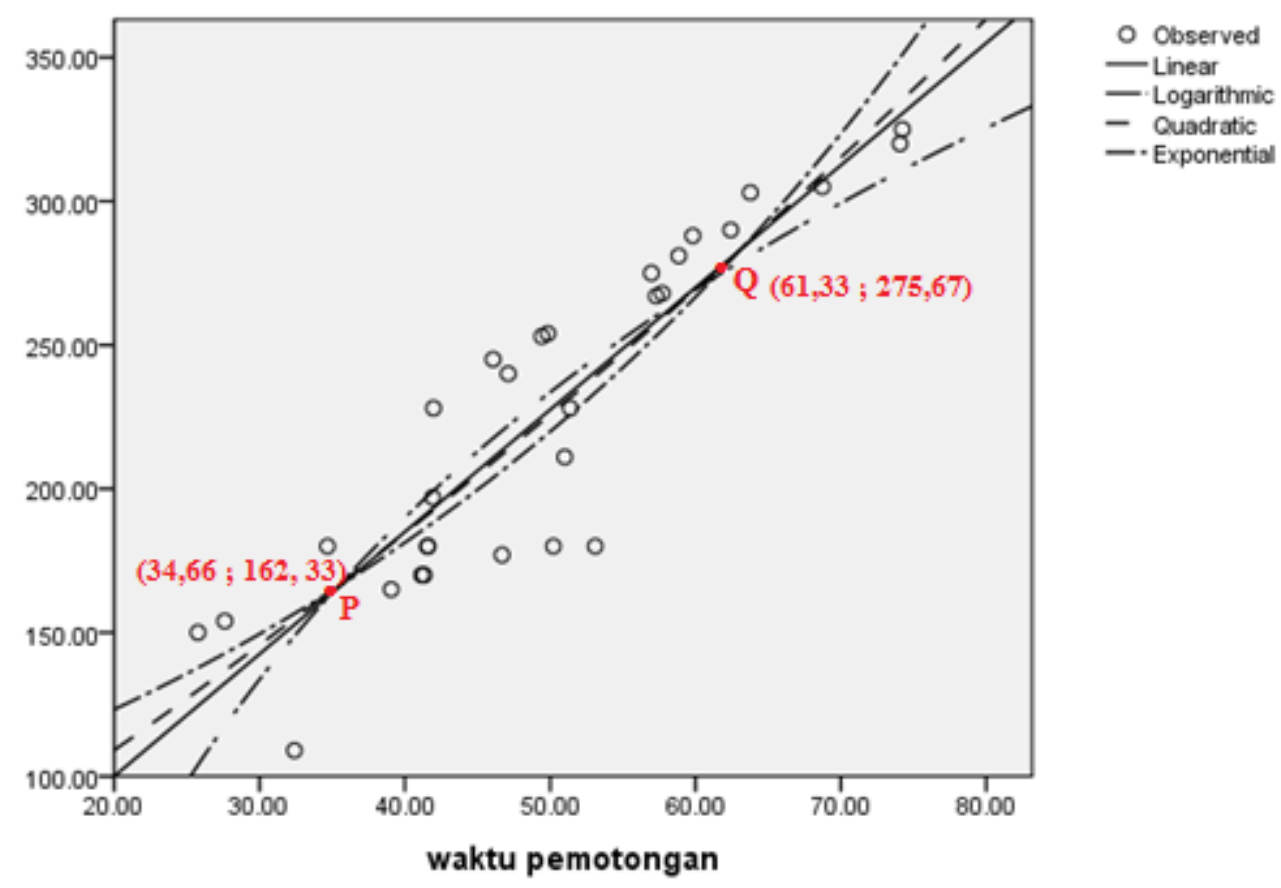

Gambar 1. Kurva waktu pemotongan terhadap waktu pemesinan

Model terbaik yang bapat digunakan sebagai model estimator waktu kerja pemesinan bubut pada uji kompetensi praktik kejuruan adalah model linear dan quadrat. Model linear dengan persamaan $\mathrm{T}_{\mathrm{m}}=15.021+4.250 \mathrm{~T}_{\mathrm{c}}$, dan model quadrat dengan persamaan $\mathrm{T}_{\mathrm{m}}=$ $42.837+3.080 \mathrm{~T}_{\mathrm{c}}+0.012 \mathrm{~T}_{\mathrm{c}}{ }^{2}$. Namun demikian, model linear lebih sederhana dibandingkan dengan model quadrat. Oleh karena itu, dipilih model linear sebagai model yang tepat digunakan sebagai estimator waktu pemesinan bubut pada uji kompetensi praktik kejuruan bidang pemesinan bubut.

Format penilaian aspek waktu kerja pemesinan dibuat berdasarkan waktu pemesinan yang ditentukan dengan model linear yang terpilih. Waktu pemesinan hasil perhitungan adalah selama 155,5 menit. Format penilaian dibuat menjadi 2 kategori yaitu go dan no go. Kategori go memiliki tiga kelompok nilai yaitu A, B, dan C masing-masing dengan skor 9,0-10;8,0-8,9; dan 7,0-7,9. Kategori no go memiliki satu kelompok nilai yaitu E tidak diberikan skor. Waktu pemesinan yang telah ditentukan kemudian ditambahkan kompensasi sebesar $10 \%$ untuk skor $9,0-10 ; 20 \%$ untuk skor $8,0-8,9$, dan $30 \%$ untuk skor 7,0-7,9. 
Tabel 3. Penilaian waktu kerja pemesinan pada uji kompetensi praktik kejuruan bidang pemesinan bubut

\begin{tabular}{cccccc}
\hline Kategori & Nilai & Skor & $\begin{array}{c}\text { Rentang Waktu } \\
\text { (Menit) }\end{array}$ & Frekuensi (F) & F (\%) \\
\hline \multirow{3}{*}{ Go } & A & $9,0-10$ & $<171$ & 6 & 20 \\
& B & $8,0-8,9$ & $171,5-187$ & 6 & 20 \\
\multirow{2}{*}{ No Go } & C & $7,0-7,9$ & $187,5-203$ & 1 & 3,33 \\
& E & - & $>203$ & 17 & 56,67 \\
& & Jumlah & & 30 & 100 \\
\hline
\end{tabular}

Nilai siswa pada uji kompetensi aspek waktu standar BSNP, seluruh siswa dinyatakan kompeten pada aspek waktu. Namun apabila aspek waktu dinilai dengan penilaian yang penulis temukan dengan nilai Kriteria Ketuntasan Minimum yang sama yaitu sebesar 7 . Terdapat perbedaan yaitu sebanyak 56,7\% siswa dinyatakan tidak kompeten pada aspek waktu. Hal ini dapat disebabkan oleh penggabungan aspek waktu, hasil dan tidak adanya patokan waktu yang jelas.

\section{KESIMPULAN}

Kesimpulan penelitian ini bahwa model linear dan quadrat adalah model terbaik yang dapat digunakan sebagai model estimator waktu kerja pemesinan bubut pada uji kompetensi praktik kejuruan.

\section{DAFTAR PUSTAKA}

Adiranti, K. K., Wardaya, Purnawan. (2016). Hubungan Waktu Kerja terhadap Hasil Kerja pada Pelaksanaan Uji Kompetensi Praktik Kejuruan Bidang Pemesinan Bubut. Journal of Mechanical Engineering Education. 3 (1). 90-98.

Badan Standar Nasional Pendidikan. (2015). Pedoman Penyelenggaraan Uji Kompetensi Keahlian (UKK) dan Sertifikasi Siswa SMK pada Ujian Nasional Tahun Pelajaran 2015/2016. Jakarta: BSNP.

Badan Standar Nasional Pendidikan. (2016). Lembar Pedoman Penilaian Ujian Praktik Kejuruan Keahlian Teknik Pemesinan Tahun Pelajaran 2016/2017. Jakarta: BSNP.

Karyadi, A., Wardaya, Purnawan. (2014). Analisis Waktu Pemesinan pada Uji Kompetensi Praktik Kejuruan Teknik Pemesinan di SMK. Journal of Mechanical Engineering Education. 1 (2). hlm. 177-182.

Nugraha, A., Wardaya, Purnawan. (2015). Hubungan antara Waktu Pemotongan dengan Waktu Pemesinan Bubut pada Uji Kompetensi Praktik Kejuruan Bidang Pemesinan. Journal of Mechanical Engineering Education. 2 (2). hlm. 165-172. 
Ramadhan, N R., Wardaya, Purnawan. (2015). Hubungan Waktu Pemotongan dan Waktu Pemesinan pada Uji Komptensi Praktik Kejuruan Teknik Pemesinan. Journal of Mechanical Engineering Education. 2 (1). hlm. 91-97. 